\title{
Observations of the Distribution and the Nature of Alpha-Active Particulate Material in a HEPA Filter Used for Plutonium-Containing Dust
}

\author{
M. T. Ryan \\ W. J. McDowell \\ G. N. Case
}




\section{DISCLAIMER}

This report was prepared as an account of work sponsored by an agency of the United States Government. Neither the United States Government nor any agency Thereof, nor any of their employees, makes any warranty, express or implied, or assumes any legal liability or responsibility for the accuracy, completeness, or usefulness of any information, apparatus, product, or process disclosed, or represents that its use would not infringe privately owned rights. Reference herein to any specific commercial product, process, or service by trade name, trademark, manufacturer, or otherwise does not necessarily constitute or imply its endorsement, recommendation, or favoring by the United States Government or any agency thereof. The views and opinions of authors expressed herein do not necessarily state or reflect those of the United States Government or any agency thereof. 


\section{DISCLAIMER}

Portions of this document may be illegible in electronic image products. Images are produced from the best available original document. 


\section{Printed in the United States of America. Available from National Technical Information Service}

U.S. Department of Commerce 5285 Port Royal Road, Springfield, Virginia 22161

Price: Printed Copy $\$ 4.00$; Microfiche $\$ 3.00$

This report was prepared as an account of work sponsored by the United States Government. Neither the United States nor the Energy Research and Development Administration/United States Nuclear Regulatory Commission, nor any of their employees, nor any of their contractors, subcontractors, or their employees, makes any warranty, express or implied, or assumes any legal liability or responsibility for the accuracy, completeness or usefulness of any information, apparatus, product or process disclosed, or represents that its use would not infringe privately owned rights. 
ORNL/TM-5765

Contract No. W-7405-eng-26

CHEMICAL TECHNOLOGY DIVISION

OBSERVATIONS OF THE DISTRIBUTION AND THE NATURE OF ALPHA-ACTIVE PARTICULATE MATERIAL IN A HEPA FILTER USED FOR PLUTONIUM-CONTAINING DUST

\author{
M. T. Ryan * \\ W. J. McDowell \\ G. N. Case \\ 1
}

Date Published: February 1977

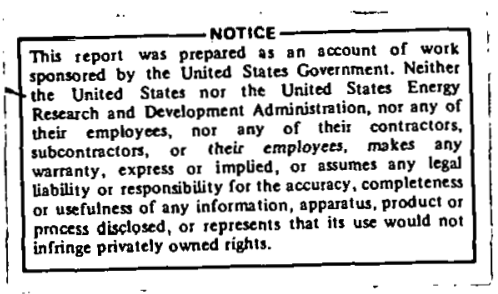

* Presently an employee of the Health Physics Division.

NOTICE This document contains information of a preliminary nature. It is subject to revision or correction and therefore does not represent a final report.

OAK RIDGE NATIONAL LABORATORY

Oak Ridge, Tenneerce 37830

operated by

UNION CARBIDE CORPORATION

for the

ENERGY RESEARCH AND DEVELOPMENT ADMINISTRATION 
OBSERVATIONS OF THE DISTRIBUTION AND THE NATURE OF ALPHA-ACTIVE PARTICULATE MATERIAL IN A HEPA FILTER USED FOR PLUTONIUM-CONTAINING DUST

M. T. Ryan

W. J. McDowe11

G.N.Ca.sE

ABSTRACT

Autoradiography has been used to determine the distribution and the nature of plutonium particulate material on a high-efficiency particulate air (HEPA) filter used to filter ${ }^{239} \mathrm{Pu}$-containing dust. Higher concentrations of alpha-active material on upstream and downstream folds of the filter indicate uneven airflow through the filter. Observations of aggregate recoil particles on the downstream face of the filter suggest that aggregate recoil transfer, a mechanism which may reduce long-term HEPA filter efficiency, may be occurring. Amounts of alpha activity found on downstream filters confirm this supposition.

\section{INTRODUCTION}

Aggregate recoil transfer ${ }^{1,2}$ is a phenomenon specific to surfaces of alpha-emitting radioactive material where, due to the kinetic energy made available by alpha decay, clusters of atoms are ejected into the surrounding medium. Such atom clusters, known as aggregate recoil particles, ${ }^{3}$ may contain up to $10^{6}$ atoms. Particles of alpha-emitting material, which are collected in normal HEPA filter operation ${ }^{4-6}$. with near $100 \%$ efficiency, may be sources of aggregate recoil particles. Aggregate recoil particles produced from a larger collected particle may 
undergo re-entrainment in the moving airstream and subsequent redeposition downstream in the filter. If an alpha decay event occurs within this particle again, re-entrainment and redeposition may occur. This process leads to a net transfer of radioactive material in the downstream direction.

It is possible to identify aggregate recoil particles by autoradiography, The image characteristics in an autoradiograph of aggregate recoil particles are different from those of larger alphaemitting particulate matter. ${ }^{7,8}$ Examples of aggregate recoil particles of ${ }^{212} \mathrm{~Pb}$ in transient equilibrium with ${ }^{212} \mathrm{~Pb}$ daughter products and a dust particle with adhering ${ }^{212} \mathrm{~Pb}$ and daughter species are shown in Figs. 1 and 2, respectively. * The aggregate-recoil-particle "star" consists of tracks moving radially outward from a central point, while the tracks from the dust particle emanate in all directions thereby defining the size and shape of the particle.

In general, the images produced in autoradiographic emulsions by larger particulate matter are asymmetric in shape and correspond to the shape of the particulate matter, whereas aggregate-recoil-particle stars appear as uniform circles. If intimate contact of the particle with the film is not achieved, the aggregate star may look like the one in Fig. 3. This aggregate recoil particle of ${ }^{212} \mathrm{~Pb}$ in transient equilibrium with its daughter products was collected on a Gelman Glass Fiber (Type A) filter medium and is interpreted as being on a subsurface fiber; hence, the particle did not make intimate contact with the autoradiographic emulsion.

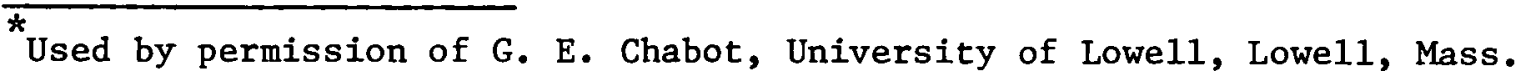


Fig. 1. Examples of "star" track pattern produced by aggregate recoil particles $\left({ }^{212} \mathrm{~Pb}\right.$ daughters). 


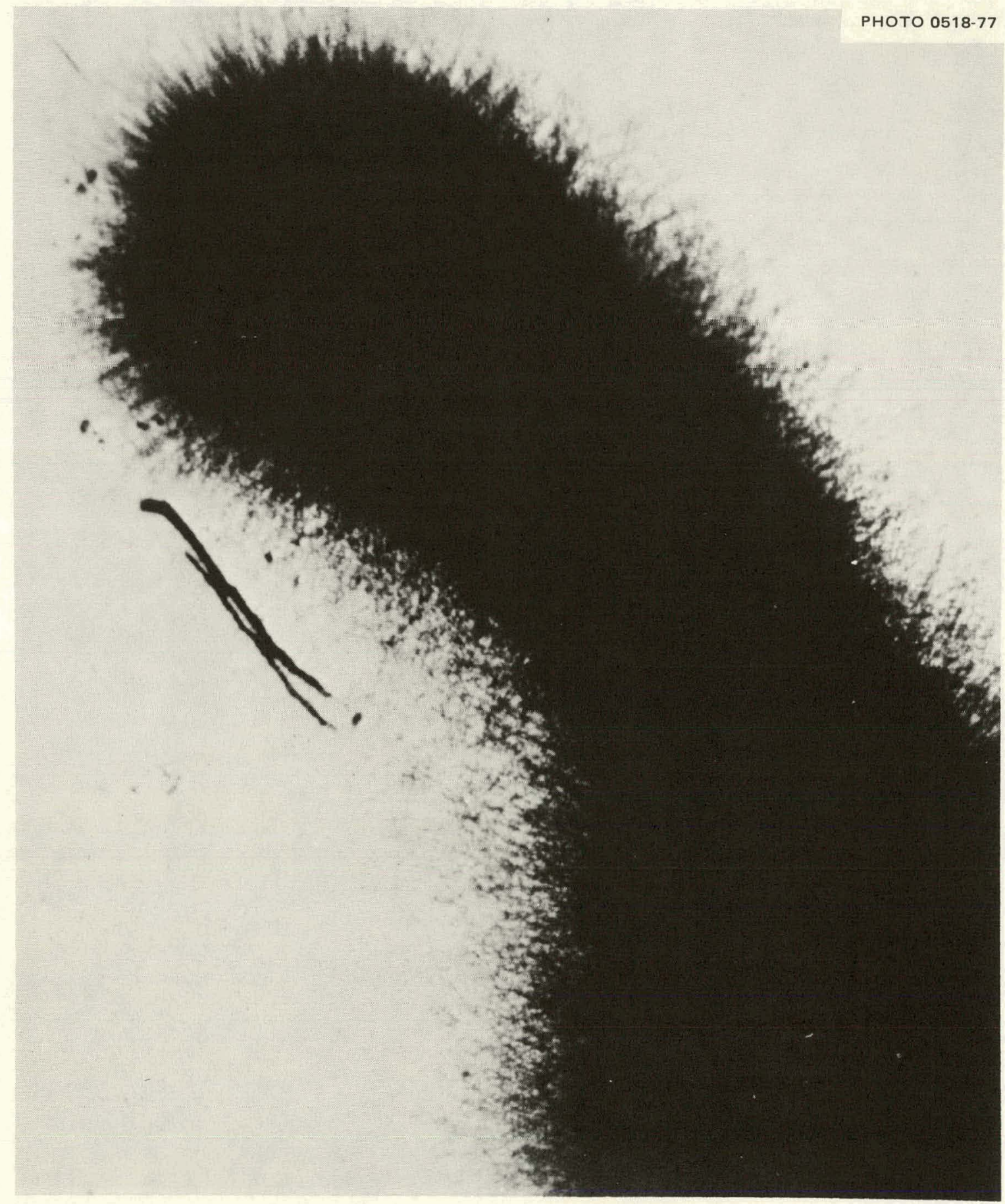

Fig. 2. Autoradiograph of alpha-active material on dust particle. 


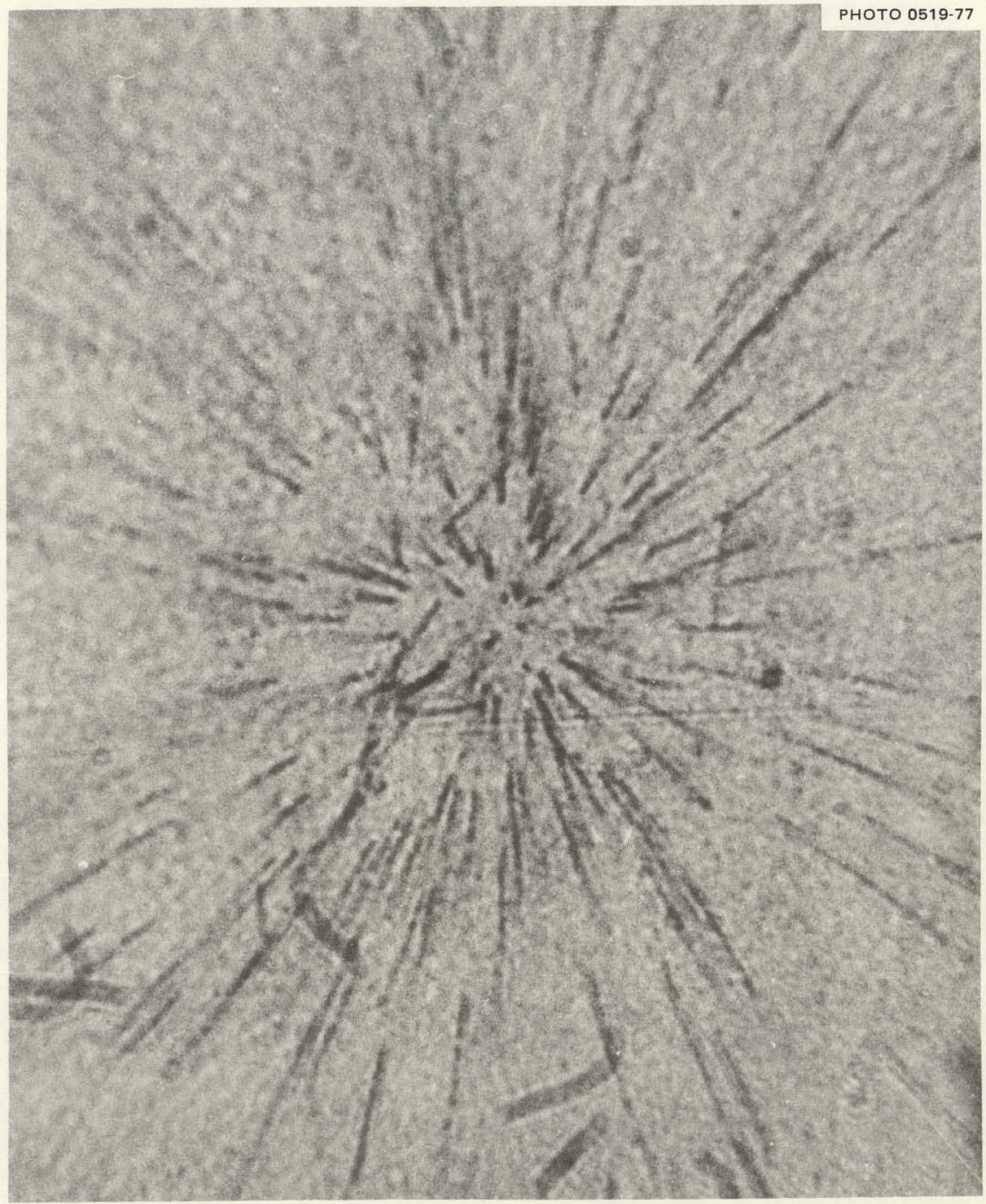

Fig. 3. Alpha tracks from an aggregate recoil particle not in intimate contact with the photographic emulsion. 


\section{EXPERIMENTAL PROCEDURE}

The HEPA filter examined was the first in a plenum of four in series and received prefiltered air from glove boxes. Since this plenum was used to filter the glove-box exit air where an 8- by 8-in. HEPA filter was used at each glove box, the first plenum filter was actually the second filter downstream of the challenging aerosol. Samples of this filter material were placed in intimate contact with Kodak Type A Personal Neutron Monitoring Film for periods of $1 \mathrm{hr}$ and $24 \mathrm{hr}$ each. Calculations indicate that an exposure of $24 \mathrm{hr}$ should be

sufficiently long to ensure that the larger $\left(10^{6}\right.$-atom) aggregate recoil particles can be visualized. Autoradiographs of both the upstream and downstream sides of the filter material were taken. The film was developed according to the procedure outlined by the Eastman Kodak Company. 9

\section{RESULTS AND DISCUSSION}

\subsection{Evidence for Recoil Particle Penetration}

A photomicrograph of an autoradiograph of the upstream side of the first filter is shown in Fig. 4. A dense distribution of tracks with particles visible as completely black areas is seen. The more asymmetric spots are probably small particles $(0.2$ to $0.4 \mu)$ that penetrated the glove-box filters. Stars are also present, indicating that much smaller particles may be buried below the surface of the filter. Very slight normal penetration by such small particles would be expected. 


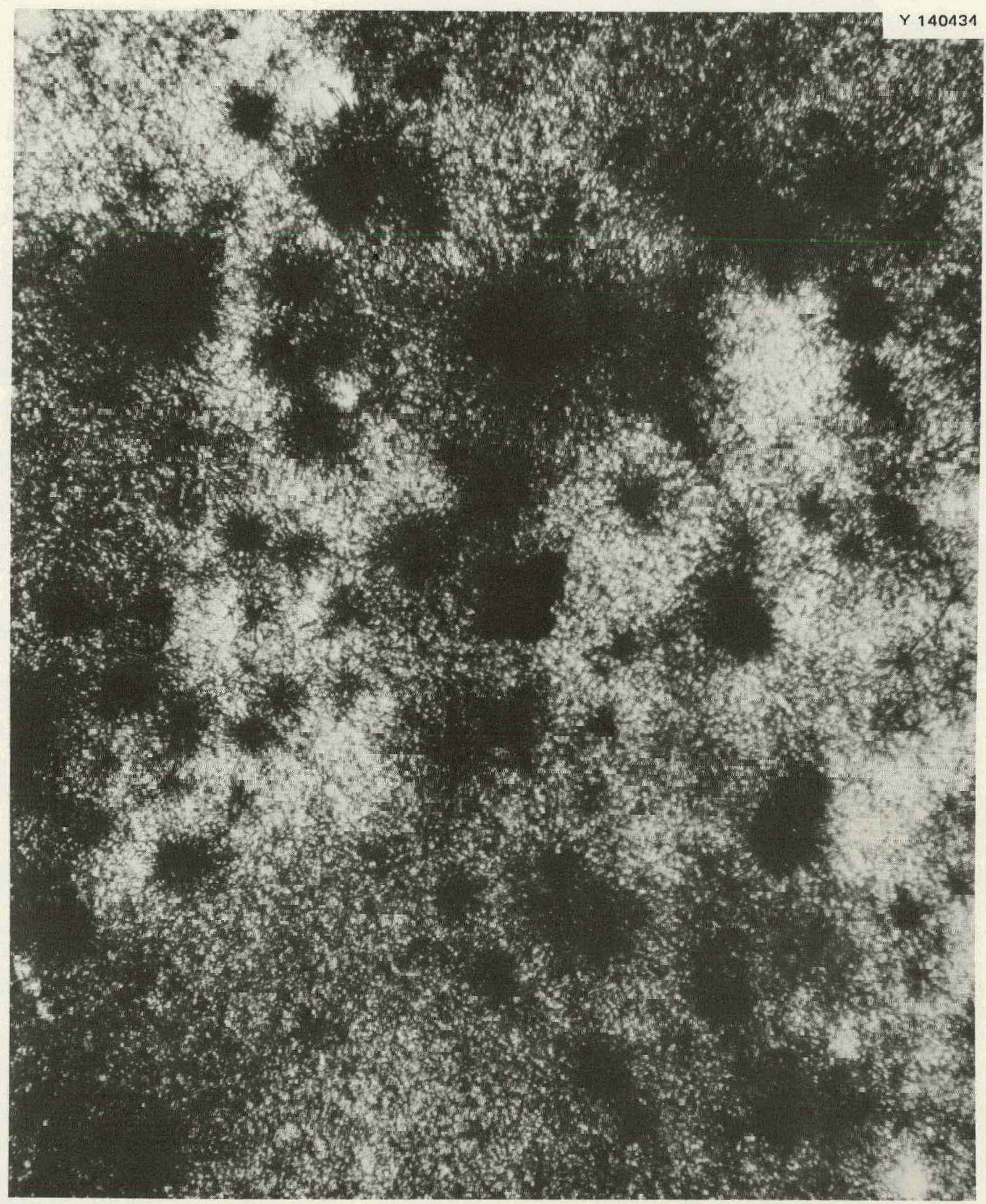

Fig. 4. Autoradiograph of the upstream surface of HEPA filter material. 
Figures 5, 6, and 7 are photomicrographs of the downstream side of 24-hr autoradiographs. All three show evidence suggesting aggregaterecoil-particle migration. Figure 5 contains several starlike arrangements of tracks that appear to be aggregate recoil particles which underwent transfer through nearly the entire filter thickness. Figure 6 shows another star in a field of much shorter tracks. These shorter tracks result when an alpha particle enters the emulsion at an angle near $90^{\circ}$ and indicate that most of the material was collected near the upstream side of the filter. Yet the aggregate recoil particle shown did penetrate the filter. As Fig. 7 suggests, varying degrees of penetration by aggregate recoil particles are possible. The rate of penetration of aggregate recoil particles through a HEPA filter is related to the specific activity of the alpha-emitting material and the particle size.

The number of particles initially generated by the source is directly related to the amount of activity present and the probability of a particle migrating is then proportional to the probability of an alpha decay within an individual particle multiplied by the number of particles present.

\subsection{Activity Distribuliun on the Filter}

Some observations have been made concerning the gross distribution of activity on this HEPA filter. Figure 8 shows a schematic view of a HEPA filter. An analysis of specific sections of the filter showed that the activity was distributed nonuniformly. The highest level of activity was found on the upstream folds, followed by the quantities found on the downstream folds and the filter faces. 


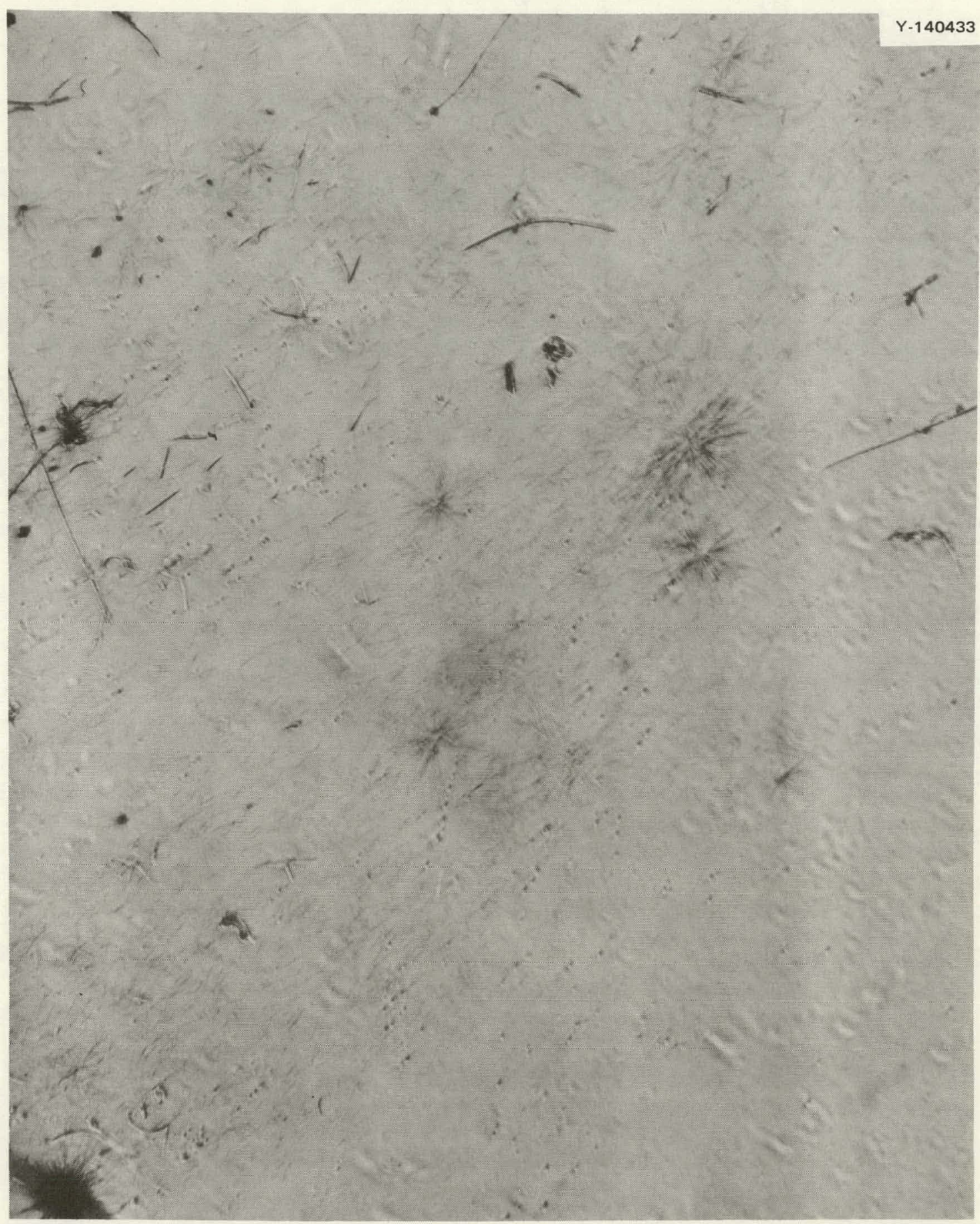

Fig. 5. Photomicrograph of autoradiograph of the downstream side of the filter material. The star-shaped alpha-track patterns are in the range of 100 to $200 \mu$ in diameter. 


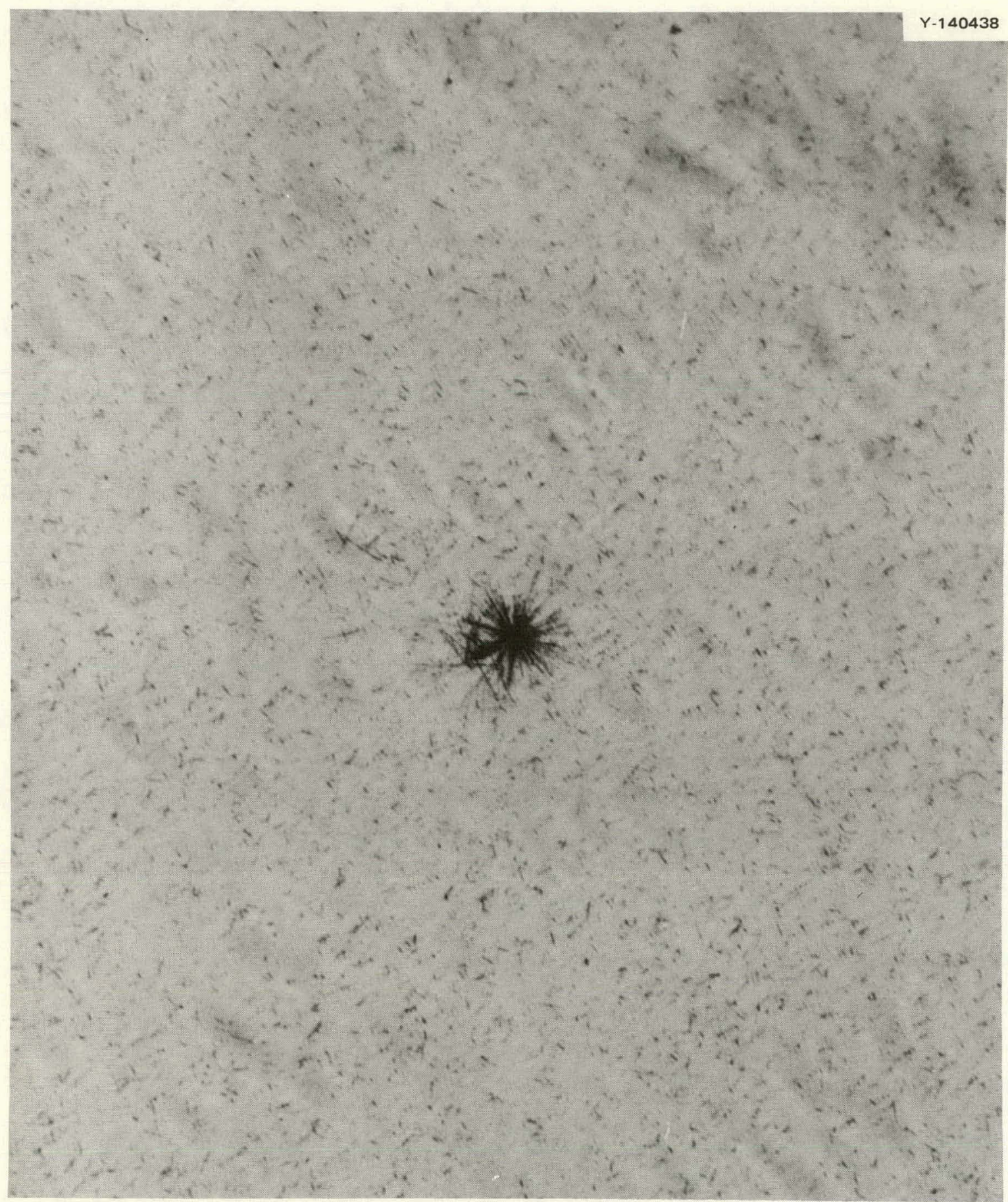

Fig. 6. Aggregate recoil particle tracks (center, approximately $50 \mu$ in diameter) contrasted with alpha particle penetration from deeper in the filter; photomicrograph of autoradiograph of downstream side of HEPA filter material. 


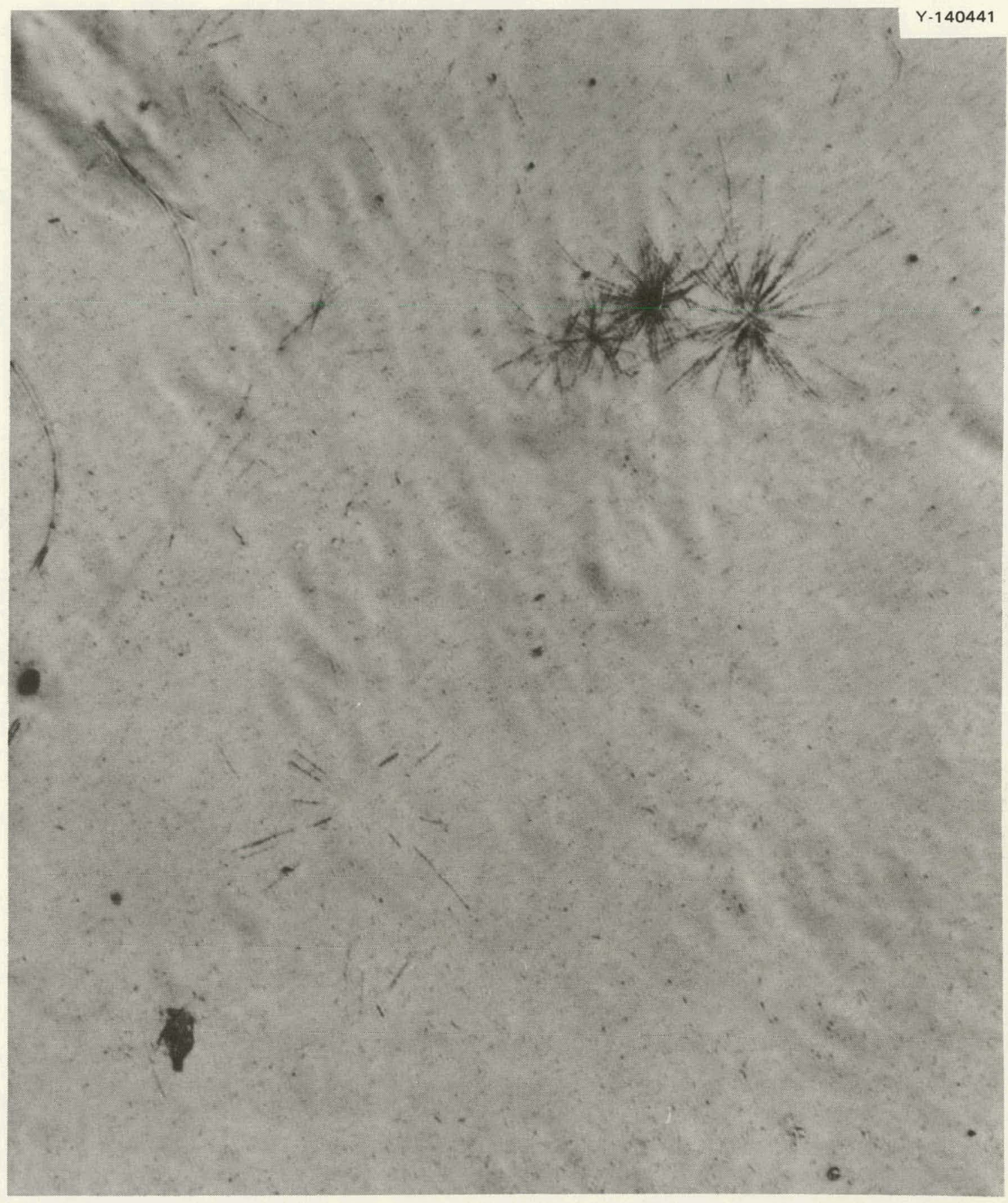

Fig. 7. Photomicrograph of autoradiograph of downstream side of HEPA filter material showing stars that appear to originate from particles at different depths in the filter material. 
ORNL DWG. 76-14603R1

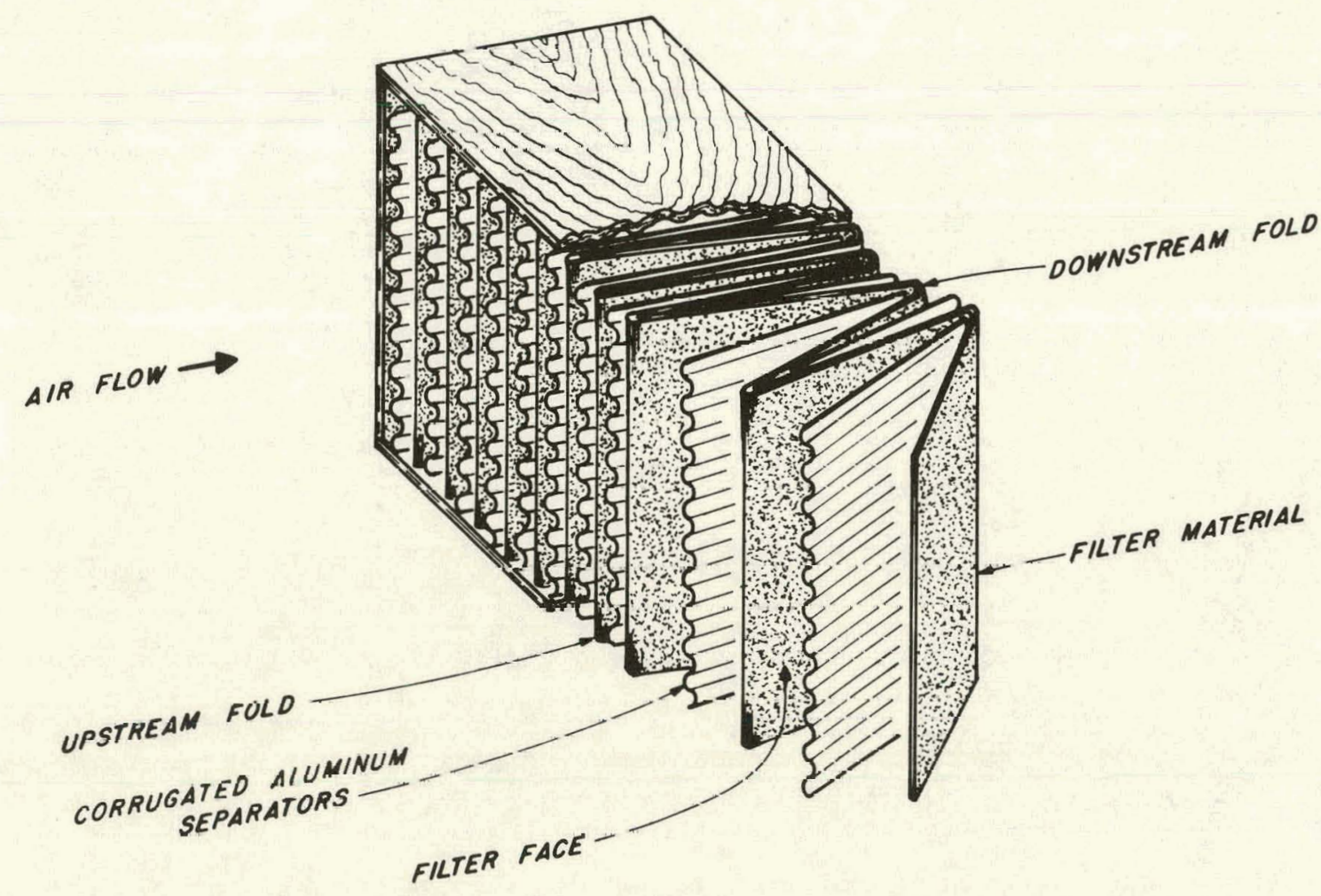

Fig. 8, Schematis view of a HEPA filter. 
If unity is assumed for the amount of activity found on the upstream folds, the relative amounts on the downstream folds and faces are 0.65 and 0.53 , respectively. This distribution of activity roughly corresponds to the amounts of dust observed on each section. An autoradiograph of this filter (Fig. 9) also shows that the aluminum support sheets inhibit flow along the lines where they are in contact with the filter.

These results indicate that deposition is not uniform over the entire area of the filter. This implies that linear flow through the filter may not be uniform.

\subsection{Distribution of Activity to Downstream Filters}

The supposition of aggregate recoil migration derived from the autoradiographs is strongly supported by the activity analyses of the downstream filters of this set and of those of a companion set. These analyses, which were done by liquid scintillation methods, ${ }^{10,11}$ will be described more fully in a separate report. The activity found and the decontamination factors (DFs) calculated for the filters are summarized in Table 1. If normal retention of aerosols is assumed, then the amount of material should decrease by a factor of $\sim 10^{3}$ from filter to filter. This is not the case; in fact, the DFs observed for the last filters are very low. The pattern of activity found on these filters is similar to that found on the filters in the laboratory experiments made to investigate aggregate recoil phenomena. ${ }^{2}$ 


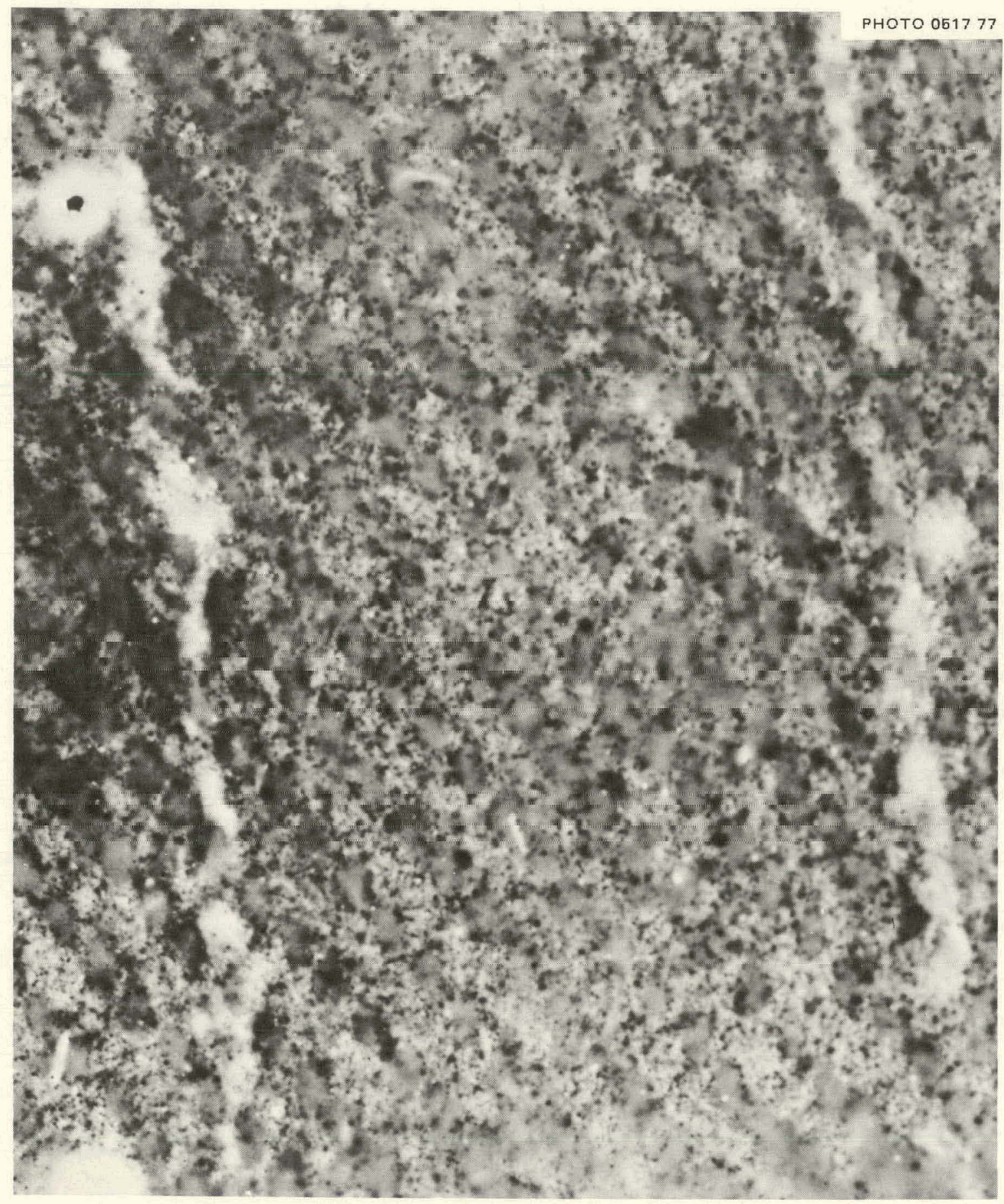

Fig. 9. Autoradiograph of the upstream side of HEPA filter material showing interference in airflow by corrugated aluminum dividers. 
Table 1. Distribution of activity on HEPA filters used for plutonium-containing dust

\begin{tabular}{|c|c|c|c|c|c|}
\hline $\begin{array}{l}\text { Filter } \\
\text { No. }\end{array}$ & $\begin{array}{c}\text { Number of } \\
\text { Determinations }\end{array}$ & $\begin{array}{l}\text { Activity level } \\
\text { (counts min-1 in.-2) }\end{array}$ & $\begin{array}{c}\text { Std } \\
\text { deviation }\end{array}$ & $\begin{array}{l}a_{\%} \text { std } \\
\text { deviation }\end{array}$ & $\mathrm{DF}$ \\
\hline \multicolumn{6}{|c|}{ Set No. 1: In use 35 months } \\
\hline 1 & 72 & 552,000 & 88 & 0.016 & $5 \times 10^{5}$ \\
\hline 2 & 3 & 0.89 & 0.015 & 1.7 & 4.2 \\
\hline 3 & 4 & 0.154 & 0.0032 & 2.1 & 2.2 \\
\hline 4 & 5 & 0.126 & 0.0024 & 1.9 & \\
\hline \multicolumn{6}{|c|}{ Set No. 2: In use 27 months } \\
\hline 1 & 66 & 22,949 & 19 & 0.08 & $4 \times 10^{4}$ \\
\hline 2 & 3 & 0.549 & 0.005 & 0.9 & 30 \\
\hline 3 & 3 & 0.0144 & 0.0003 & 1.9 & 4.3 \\
\hline 4 & 3 & 0.0044 & 0.00016 & 3.7 & \\
\hline & & $\cdot$ & & & . \\
\hline
\end{tabular}

${ }^{a}$ Calculated from total counts collected, total background, and total counting times.

${ }^{b}$ Calculated by assuming that the total activity found on downstream filters escaped the preceding filter. 


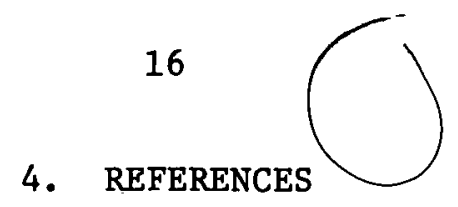

1. M. 'T. Ryan, K. W. Skrable, and G. E. Chabot, Health Phys. 29, "Retention and Penetration Characteristics of a Glass Fiber Filter for ${ }^{212} \mathrm{~Pb}$ Aggregate Recoil Particles," 796-98 (1975).

2. W. J. McDowe11, F. G. Seeley, and M. T. Ryan, "Penetration of HEPA Filters by Alpha Recoil Aeroso1s," in Proceedings of the 14th ERDA Air Cleaning Conference, Sun Valley, Idaho (in press).

3. R. W. Lawson, "The AgBitegale Recull uf Radioactive Substances Emitting $\alpha$-Rays," Nature 102, 464-65 (1919).

4. C. N. Davies, Air Filtration, Academic, New York, 1973 .

5. W. B. Seefeldt, W. J. Mecham, and M. J. Steindler, Characterization of Particulate Plutonium Released in Fuel Cycle Operations, ANL-75-78 (1970).

6. R. J. Davis, A Nuclear Safety Partic1e Primer, ORNL=4337 (1969).

7. J. A. Hayden, "Characterization of Environmental Plutonium by Nuclear Track Tecluiques," pp. 648-60 in Atmosphere - Surface Exchange of Particulate and Gaseous Pollutants (1974) (Proceedings of a symposium held at Richland, Wash., Sept. 4- , 1974), CONF-740931 (1976).

8. N. W. Nathans, K. Reinhart, and W. D. Holland, "Methods of Analysis Useful in the Study of Alpha-Emitting and Fissionable Materialcontaining Particles," pp. 661-73 in Atmosphere - Surface Exchange of Particulate and Gaseous Pollutants (1974) (Proceedings of a symposium held at Kichland, Wash., Sept. 4-6, 1974), CONF-740921 (1976). 
9. Eastman Kodak Company, Data Release, Kodak Materials for Nuclear Physics and Radiography.

10. W. J. McDowe11, D. T. Farrar, and M. R. Billings, "Plutonium and Uranium Determination in Environmental Samples: Combined Solvent Extraction-Liquid Scintillation Method," Talanta 21, 1231-45 (1974).

11. W. J. McDowell and J. F. Weiss, "Liquid Scintillation Alpha Counting and Spectrometry and its Application to Bone and Tissue Samples," Health Phys. (in press). 
THIS PAGE

WAS INTENTIONALLY

LEFT BLANK . 
ORNL/TM-5765

INTERNAL DISTRIBUTION

1. J. A. Auxier

2. K. B. Brown

3. W. D. Burch

4. C. A. Burchstead

5. T. J. Burnett

6. H. M. Butler

7. C. F. Coleman

8. F. L. Culler

9. D. E. Ferguson

10. J. E. Kahn

11. R. A. Lorenz

12. A. P. Malinauskas

13-22. W. J. McDowell

23. E. L. Nicholson

24. G. W. Parker
25-29. M. T. Ryan
30. F. G. Seeley
31. R. R. Shoun
32. B. I. Vondra
33. R. G. Wymer
34. 0. 0. Yarbro
35. A. Zucker
36. C. H. Ice (Consultant)
37. E. L. Gaden (Consultant)
38. R. B. Richards (Consultant)
39-40. Central Research Library
41. Document Reference Section
42-51. Laboratory Records
52. Laboratory Records-RC
53. ORNL Patent Office

\section{EXTERNAL DISTRIBUTION}

54. H. J. Ettinger, University of California, Los Alamos, Scientific Laboratory, P.0. Box 1663, Los Alamos, NM 87545.

55. R. D. Gaskins, Rockwell International, Rocky Flats Plant, P.0. Box 888, Golden, CO 80401 .

56. Research and Technical Support Division, ERDA, ORO.

57-83. Technica1 Tnfnrmation Center, Oak Ridge, TN 37830.

84. Ed Vejvoda, Rockwell International, Rocky Flats Plant, P.o. Box 888, Golden, C0 80401 .

85. Dick Woodard, Rockwe11 International, Rocky Flats Plant, P.o. Box 888, Golden, CO 80401 . 